\title{
2 - Machado de Assis, ficção e suporte
}

\author{
Lúcia Granja
}

\section{SciELO Books / SciELO Livros / SciELO Libros}

GRANJA, L. Machado de Assis, ficção e suporte. In.: Machado de Assis - antes do livro, o jornal: suporte, mídia e ficção [online]. São Paulo: Editora Unesp, 2018, pp. 61-100. ISBN: 978-85-9546-281-6. https://doi.org/10.7476/9788595462816.0003.

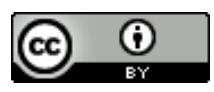

All the contents of this work, except where otherwise noted, is licensed under a Creative Commons Attribution 4.0 International license.

Todo o conteúdo deste trabalho, exceto quando houver ressalva, é publicado sob a licença Creative Commons Atribição 4.0.

Todo el contenido de esta obra, excepto donde se indique lo contrario, está bajo licencia de la licencia Creative Commons Reconocimento 4.0. 


\section{2 \\ MACHADO DE Assis, FICÇão E SUPORTE}

\section{Outras palavras}

Inserido em uma "civilização do jornal", Machado de Assis aproveitou a matriz jornalística em sua composição literária, uma das novidades que conferem modernidade à sua obra. Essa ideia amplia a de que, a partir das crônicas do início dos anos 1860, o escritor aperfeiçoou paulatinamente sua técnica, experimentando e experienciando a ficção, a crítica literária, assim como a habilidade retórica em relação aos discursos vigentes, práticas e acontecimentos miúdos da vida social e política, tudo isso se utilizando de um jogo crítico-paródico com as formas (textos da tradição literária e discursos parlamentares, entre outros textos do jornal) (Granja, 2000).

Neste capítulo, compartilho o desejo de contribuir com a reflexão de Antonio Candido. Em sua história da literatura brasileira, no capítulo "A literatura e a vida social", o mestre paulista associou a produção literária brasileira às condições de produção e circulação da literatura no país no século XIX, entendendo-a como um "processo comunicativo, que é integrador e bitransitivo por excelência" (Candido, 1995, p.22). Já em “O escritor e o público”, Candido (ibidem, p.85-6) explica, como lembra Hélio Guimarães, a acessibilidade da literatura então produzida no Brasil por sua facilidade, 
baixo grau de hermetismo, tendo o escritor produzido para públicos simpáticos embora restritos, geralmente pertencentes às pequenas elites, de grande pobreza cultural.

No entanto, segundo o crítico machadiano, "em complementação à argumentação de Candido, é de se notar que a acessibilidade das obras também está relacionada ao fato de que o principal veículo de escoamento da produção literária oitocentistas era o jornal" (Guimarães, 2004, p.49). Na sequência, ele extrai de Machado Neto (1973, p.231 apud Guimarães, 2004, p.50) a afirmação de que "os literatos foram os iniciais olimpianos do primeiro mass media usado no Brasil - o jornal", e desdobra-a em uma característica importante da literatura brasileira:

a convivência constante num mesmo veículo entre todos os tipos de produção literária, que inclui todos os matizes que há entre o que hoje seria considerado alta e baixa literatura [...] que na obra machadiana ficará evidenciada com a assimilação ao romance, principalmente a partir de Brás Cubas, de técnicas da crônica jornalística e do folhetim. (Guimarães, 2004, p.50)

Dessa forma, se algumas características da literatura brasileira e de Machado de Assis fazem parte de um processo civilizacional mais amplo, a refinada leitura dos textos machadianos já capturara, nas entrelinhas, os indícios dessa vinculação. O mesmo está em uma percepção de Silvia Azevedo (2013a, p.15), que analisa a obra do crítico-cronista Machado de Assis:

Enquanto Gonçalves de Magalhães, Pereira da Silva e Joaquim Norberto e Santiago Nunes Ribeiro estavam empenhados em identificar e avaliar os autores do passado para integrá-los ao corpus literário brasileiro, Machado de Assis, como crítico literário, dará prioridade às produções do presente, ambas as atividades, o exercício da crítica e o da criação literária, relacionadas ao desenvolvimento da imprensa. Nesse sentido, os dois ensaios de 1859, "O jornal pelo livro" e "A reforma pelo jornal", o primeiro publicado no 
Correio Mercantil e o segundo em O Espelho, não apenas manifestam o entusiasmo do jovem Machado com as tendências democráticas do jornalismo, mas também compreendem o novo veículo de difusão cultural como instrumento promissor na profissionalização do homem de letras, com repercussões, poder-se-ia acrescentar, na atuação do crítico literário. Se a carreira do literato se construía, predominantemente, nas páginas dos periódicos, o mesmo acontece com os escritores na prática ocasional da "crítica viva", a crítica que manifesta a personalidade daquele que julga e a preocupação com o texto do ponto de vista da construção literária.

Temos aqui o alto grau de consciência que o jovem Machado declarava em relação ao jornal como veículo para a profissionalização dos homens de letras, além daquela mesma experiência em relação à ficção e à crítica por meio da atividade jornalística. Segundo Machado (2013a, p.72), em “O jornal e o livro”, de 1859, se a invenção da imprensa e, depois dela, a democratização do livro haviam sido um progresso, "faltava ainda alguma coisa; não era ainda a tribuna comum aberta à família universal, aparecendo sempre com o sol e sendo com ele o centro de um sistema planetário”. Está claro, dessa perspectiva, que o jovem escritor brasileiro partilhava com seus pares europeus - escritores-jornalistas como Théophile Gautier, altamente conscientes das possibilidades e características do novo veículo - a incorporação ideológica e também estética, como se poderá observar, da mudança civilizacional causada pelo jornal, assim como da vasta comunicação que são dela, ao mesmo tempo, causa e consequência.

Ao longo dos anos, viriam todas as possibilidades de explorar poeticamente o novo sistema e mesmo de desconstruí-lo, o que se demonstra, por exemplo, na análise que Ana Claudia Suriani da Silva (2015, p.179-85) faz do Quincas Borba, quando, na publicação em livro, a passagem do tempo da história deixa de imitar o tempo real. Azevedo observou ainda algo fundamental, o fato de que, como crítico, nesse novo veículo, Machado se debruça sobre a novidade, as "produções do presente". Certamente essa preferência pela 
produção contemporânea era reforçada pelos vários "agentes" que lutavam durante o processo de autonomização do campo literário brasileiro (Bourdieu, 1990; 1992).

O terceiro apoio machadiano deste capítulo é a afirmação de Santiago (1978, p.29-30):

Já é tempo de se recomeçar a compreender a obra de Machado de Assis como um todo coerentemente organizado, percebendo que certas estruturas primárias e primeiras se desarticulam e se rearticulam sob a forma de estruturas diferentes, mais complexas e mais sofisticadas à medida que seus textos se sucedem cronologicamente.

A ideia do desdobramento de estruturas - e, ampliando, temas, ideias, exercícios, transposições - que se sofisticam de acordo com o desenvolvimento da obra literária de Machado é fundamental à medida que, debruçado sobre a matriz do jornalismo (noticioso, crítico, literário), as repetições de temas e reescrita das obras, já apontadas pela crítica machadiana, ressignificam-se. John Gledson (2008, p.166), sem negar a transposição de gêneros ou especificamente pensando na ficção, pois estava interessado no conto "A parasita azul" (1872), identifica que a experimentação foi conduzida "em diversas frentes e vemos casos que parecem experiências deliberadas, tentativas de exercitar certos modelos ou ideias para ver em que medida funcionam, e alcançam diferentes estágios de acabamento e de sucesso (ou fracasso) artístico".

Dessa forma, na tentativa de compreensão da "busca lenta e medida do esforço criador em favor de uma profundidade que não é criada por um talento inato, mas pelo exercício consciente e duplo, da imaginação e dos meios de expressão" (ibidem, p.30), as crônicas da década de 1870 funcionam como centros irradiadores de novidade, notadamente as imediatamente anteriores à "crise" que Machado de Assis atravessava em uma "história de progresso contínuo” (Gledson; Granja, 2008, p.17) de sua literatura. Depois delas, entram em cena grandes contos. 


\section{Aquele escritor monstruoso: da crônica ao conto}

Logo antes da construída e refletida mudança que levaria Machado de Assis à escrita das Memórias Póstumas de Brás Cubas (1880), o escritor esteve, nas crônicas, às voltas com um material de natureza bastante variada e um universo midiático (o jornal) que lhe deram assunto e o ajudaram a configurar soluções estéticas em sua ficção.

Como mostram os escritos para o jornal O Cruzeiro, ${ }^{1}$ na virada dos anos 1870 para 1880, o "feio" passou a integrar esteticamente a ficção de Machado de Assis, muitas vezes por meio de um ponto de vista narrativo que observava quase cruamente a naturalização do sadismo nas relações de poder; simultaneamente existia, por parte do cronista, ainda em relação ao "grotesco", ${ }^{2}$ uma severa crítica à forma como se apresentavam ao público os espetáculos de entretenimento, ao mesmo tempo em que se procurava denunciar a facilidade com que se "corrompia" o gosto, por meio de exibições e espetáculos principalmente interessados no lucro, que no discurso da imprensa eram manipuladores das opiniões de nossos reduzidos públicos.

Cada vez mais frequentemente, à ficção machadiana do final dos anos 1870 e início dos anos 1880 compareceriam casos que

1 Além das crônicas para este mesmo jornal, O Cruzeiro, Machado de Assis produziu matéria de natureza variadíssima, desde Iaiá Garcia, publicado em capítulos, até textos quase inclassificáveis, chamados por José Galante de Sousa de conto ("O califa de platina"), fantasia ("O bote de rapé”) e diálogo em verso ("Antes da missa”), entre outros, como "O caso Ferrari”, incluído pela edição da Jackson na crítica teatral. As edições posteriores das obras completas dispersaram esses textos em várias classificações: miscelânea, crítica literária, crônica. Todos eles, do romance às crônicas, passando pela "vária" (termo de Galante de Sousa) e pelas críticas ao romance O primo Basílio, saídos no mesmo jornal, na mesma época, vêm assinados pelo pseudônimo "Eleazar". Para uma discussão preliminar a respeito de um significado geral para esse material reunido, ver Gledson \& Granja (2008).

2 As categorias estéticas do "feio" e do "grotesco" não serão aqui esmiuçadas pela complexidade teórica do debate, que desviaria o foco crítico do livro. É importante observar de que forma Machado de Assis as atualiza em seu fazer literário, a partir do uso romântico dos conceitos, colhido no texto célebre de Victor Hugo (2002), escrito em 1827, "Do grotesco e do sublime", prefácio ao drama Cromwell. 
enunciavam, em um esforço medido (Moraes, 2009, p.274), aquilo que repugnava ao leitor. Nas Memórias Póstumas de Brás Cubas, por exemplo, os escravos ocuparam essa posição, o que se pode verificar na conhecidíssima cena na qual Brasinho cavalgava um moleque da casa, Prudêncio, fustigando-o com uma varinha, depois de ter-lhe enfiado um cordel no queixo "à guisa de freio" (Machado de Assis, 2008d, v.1, p.638), ou ainda, na mesma cena de reminiscência, quando o "menino diabo" quebrou a cabeça de uma escrava que lhe negara uma colher de um doce de coco em preparação; quanto ao Brás já adulto, no capítulo "O verdadeiro Cotrim”, seu cunhado é descrito como conhecido por sua barbárie, mas talvez injustamente, segundo o narrador, posto que "o único fato alegado nesse particular era o de mandar com frequência escravos ao calabouço, donde eles desciam a escorrer sangue" (ibidem, p.737). Os exemplos continuariam ainda pelo contos "A causa secreta", "O enfermeiro", "Sem olhos", vários outros trechos dos romances, mas os casos citados são suficientes à sustentação da ideia de que o horripilante, aqui recortado a partir do abuso do corpo humano e animal em relações que envolvem várias manifestações do poder, é incorporado à ficção machadiana como paródia da naturalização de certos discursos e práticas das sociedades em geral.

Melhor dizendo, na ficção, a legitimação da violência pelos procedimentos da criação e, sobretudo, pelo relato quase desumanizado dos narradores desvela a matéria do viver, inclusive em seu inverossímil. Já nas crônicas, nas quais a ficção comparece apenas como possibilidade e não como condição do discurso, a matéria geral é destrinchada pelo comentário irônico e, nesse caso, o tratamento dado ao grotesco, sem a intermediação da ficção, é a revisão de discursos e ideologias.

3 Eliane Robert de Moraes (2009, p.271-88) mostra que no conto "A causa secreta", o pormenor com que se narra a cena em que Fortunato tortura um rato, detalhamento estranho às descrições dos textos machadianos, indica a forma de prazer que se associa à do sádico, surpreendente em Machado, por assumir contornos bem mais verossímeis do que as fabulações de crueldade do próprio Marquês de Sade. 
Como se sabe, entre maio e setembro de 1878, ao longo de 14 domingos, Machado de Assis publicou a série de crônicas "Notas semanais" em O Cruzeiro, ali ocupando o espaço do rodapé do jornal diário, captando os variados assuntos políticos e culturais das semanas que esses textos revisavam. Nessa série, entre esses fatos transformados em assuntos, como mencionado no capítulo anterior, estavam a exposição de um cavalo de oito pernas, os espetáculos oferecidos ao público por um "homem-peixe" e por um anão sem braços, a euforia carioca pela tauromaquia e, de modo mais abrangente, aquilo que o cronista entendia como a degradação dos interesses manifestados pelos leitores e plateias.

Com o foco nos espetáculos que envolviam os touros, observa-se que eles já haviam antes aparecido como índice das relações entre poder e gosto. Machado de Assis já mencionara as touradas nos textos da série "Ao acaso", publicados no Diário do Rio de Janeiro entre 1864 e 1865, mas o assunto foi se tornando cada vez mais polêmico nas crônicas do escritor posteriores a 1876.

As touradas procuravam acentuar o vínculo do Brasil com a Coroa portuguesa e se fizeram presentes na colônia desde o século XVIII. Seguiam, é claro, o modelo da corrida portuguesa, em que não se mata o touro. Em geral, elas eram realizadas no Campo de Sant'Anna, mas ele foi transformado em uma praça no início dos anos 1870, o que deu lugar a uma nova fase, na qual as arenas eram montadas pelos organizadores ou, como na época das crônicas em questão, realizadas no "circo de Botafogo", uma arena de alvenaria erguida nesse bairro para abrigar tal tipo de espetáculo.

Nesse contexto, em 11 de março de 1877, a Gazeta de Notícias de domingo trouxe o anúncio da "Grande tourada. Extraordinária corrida" ${ }^{4}$ que seria realizada às 16 horas daquele dia, em benefício

4 Anunciam-se os dois espetáculos, "tourada" e "corrida", graças à natureza das touradas portuguesas. No início, os cavaleiros, vestidos com trajes nobres portugueses do século XVII, desafiam e combatem os touros com as bandeirolas. A seguir, os forcados seguram e fazem parar os touros pelos chifres, em uma espécie de corrida a pé. O mesmo tipo de tourada é praticado em algumas cidades da região do Midi, na França. 
Figura 12 - Gazeta de Notícias, Rio de Janeiro, 11 de março de 1877, p.4

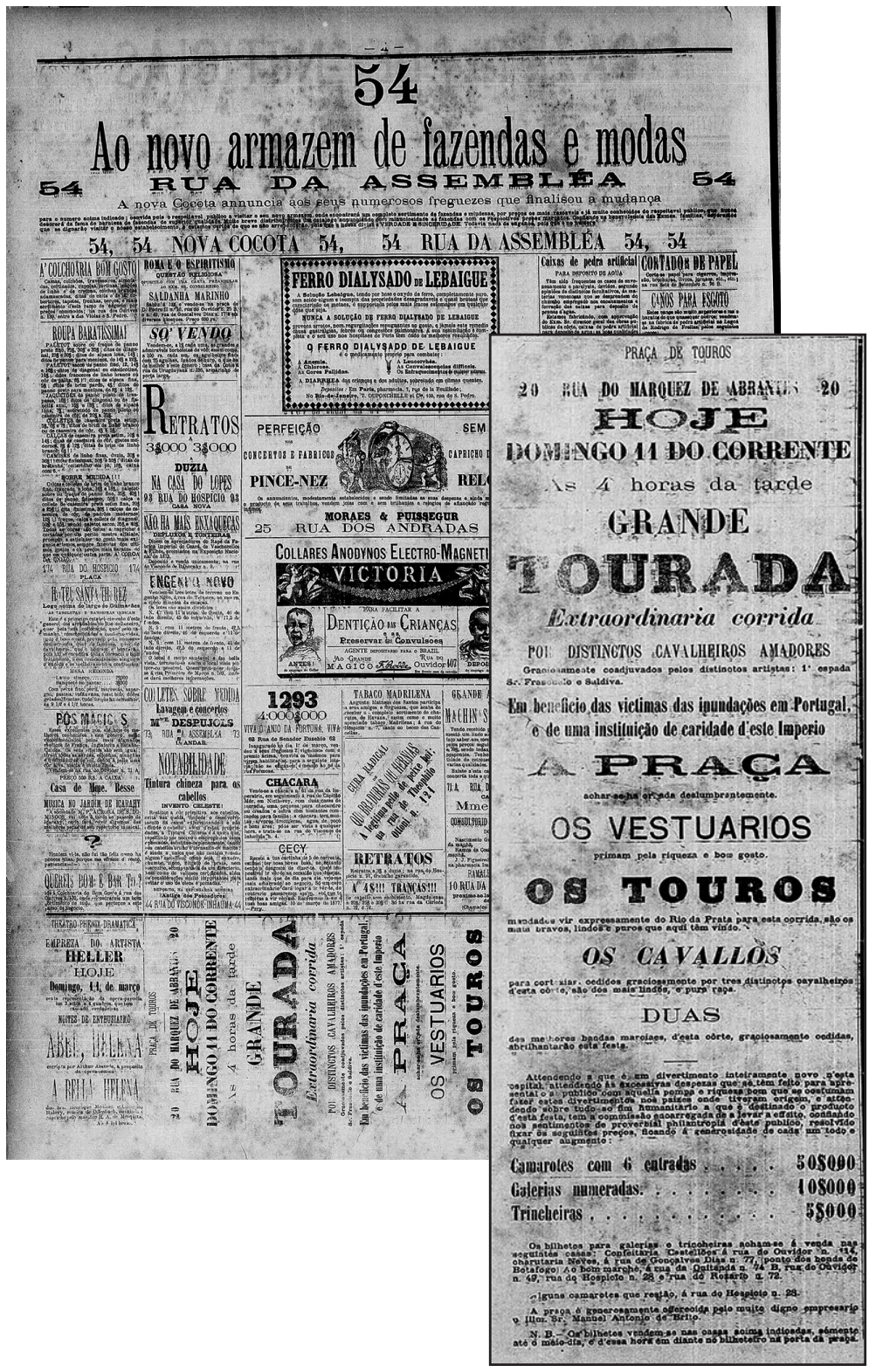

Fonte: Imagens adquiridas junto à Biblioteca Nacional do Rio de Janeiro pelo Projeto Temático Fapesp A circulação transatlântica dos impressos. 
das vítimas das enchentes em Portugal e de uma instituição de caridade não nomeada no anúncio. A imagem mostra que o anúncio ocupou espaço considerável da quarta página do jornal.

No final do anúncio em questão, na parte inferior, à direita da página, impressa horizontalmente, lê-se:

Atendendo a que é um divertimento inteiramente novo nesta capital, atendendo às excessivas despesas que se tem feito para apresentá-lo ao público com aquela pompa e riqueza com que se costumam fazer esses divertimentos nos países onde tiveram origem, e atendendo sobretudo ao fim humanitário a que é destinado o produto desta festa, tem a comissão encarregada de a levar a efeito, confiando nos sentimentos de proverbial filantropia deste público, resolvido fixar os seguintes preços, ficando à generosidade de cada um todo e qualquer aumento:

Camarotes com 6 entradas $50 \$ 000$

Galerias numeradas $10 \$ 000$

Trincheiras $5 \$ 000$

Os bilhetes para galerias e trincheiras acham-se à venda nas seguintes casas: confeitaria Castelões, à Rua do Ouvidor n ${ }^{\circ} 114$, charutaria Neves à Rua Gonçalves Dias n ${ }^{\circ} 77$, ponto de bonde de Botafogo, ao Bon Marché à Rua da Quintanda n ${ }^{\circ} 74 \mathrm{~B}$, Rua do Ouvidor $n^{\circ}$ 49, Rua do Hospício, n 28 e Rua do Rosário n 72. [... . ${ }^{5}$

O anúncio qualifica o "novo divertimento" em questão, acentuando a "pompa" e "riqueza" da "festa": a praça estava ornada deslumbrantemente; os touros, mandados vir do Rio da Prata, eram os mais bravos, lindos e puros; os cavalos eram também os mais lindos e de pura raça, tudo isso animado por duas das melhores bandas marciais e corroborado nos jornais dos dias subsequentes por artigos de glorificação do evento.

5 Gazeta de Notícias, Rio de Janeiro, 11 mar. 1877, "Anúncios”, p.4. Consulta: imagens adquiridas junto à Biblioteca Nacional do Rio de Janeiro pelo Projeto Temático Fapesp A circulação transatlântica do impresso. 
Ainda em relação ao anúncio, parece também que se procura justificar variados aspectos da "festa". Em primeiro lugar, o texto tenta desfazer eventuais julgamentos negativos, oriundos da natureza do espetáculo, uma vez que o discurso pelo respeito à vida e ao bem-estar dos animais já era corrente àquela época, ${ }^{6}$ mesmo que o Brasil ainda fosse esperar algumas décadas para ver nascer uma sociedade protetora dos animais. Em seguida, explicam-se os valores dos ingressos, a partir da contrapartida do propósito humanitário que essas touradas teriam, apelando-se também à "proverbial filantropia" do público, no caso de eventuais valores adicionais. Ao mesmo tempo, os diferentes tipos de lugares e ingressos, assim como a grande rede de pontos de venda desses ingressos, podem nos dar impressão de que a tourada era um espetáculo preparado para variados bolsos. No entanto, sendo um ingresso para um dos lugares mais comuns vendido a cinco mil réis, ele parece efetivamente caro, posto que alguns anúncios saídos na Gazeta de Notícias à mesma época mostram que a assinatura anual desse jornal diário custava doze mil réis; ${ }^{7}$ já a assinatura anual do periódico bimensal ilustrado $O$ Mosquito podia ser adquirida por dezesseis mil réis; ${ }^{8}$ enquanto isso, um ingresso para uma exposição em cartaz no Teatro São Pedro era anunciada a mil réis, com 50\% de desconto para as crianças. ${ }^{9}$ Delso Renault (1978, p.61-2), que descreve algumas formas de lazer no Rio de Janeiro da metade dos anos 1850, confirma-nos a impressão de que não estamos realmente diante de um evento para os setores menos afortunados da população: segundo o historiador, o espetáculo popular era o circo, sendo o teatro caro para o grande público. Ainda segundo

6 Conferir, por exemplo, Victor Hugo (1884) e Arthur Schopenhauer (1887).

7 Gazeta de Notícias, Rio de Janeiro, 22 fev. 1877, "Cabeçalho”, p.1. Consulta: imagens adquiridas junto à Biblioteca Nacional do Rio de Janeiro pelo Projeto Temático Fapesp A circulação transatlântica do impresso.

8 Gazeta de Notícias, Rio de Janeiro, 22 fev. 1877, “Anúncios”, p.4. Consulta: imagens adquiridas junto à Biblioteca Nacional do Rio de Janeiro pelo Projeto Temático Fapesp A circulação transatlântica do impresso.

9 Gazeta de Notícias, Rio de Janeiro, $1^{\circ}$ mar. 1877, "Anúncios", p.4. Consulta: imagens adquiridas junto à Biblioteca Nacional do Rio de Janeiro pelo Projeto Temático Fapesp A circulação transatlântica do impresso. 
Renault, uma tentativa de tourada em um circo havia acabado muito mal, uma vez que os espectadores se haviam sentido logrados.

Em suma, a observação atenta do anúncio de 11 de março de 1877 mostra grande parte das razões que motivaram a veemente crítica machadiana publicada em "História dos quinze dias", Illustração Brasileira, em 15 de março, quatro dias depois. Nesse dia, em o cronista apresenta uma visada da festa que em nada confirma o espírito oficial ou publicitário dela:

O certo é que se eu quiser dar uma descrição verídica da tourada de domingo passado, não poderei, porque não a vi.

Não sei se já disse alguma vez que prefiro comer o boi a vê-lo na praça.

Não sou homem de touradas; e se é preciso dizer tudo, detesto-as. Um amigo costuma dizer-me:

- Mas já as viste?

- Nunca!

- E julgas do que nunca viste?

Respondo a este amigo, lógico mas inadvertido, que eu não preciso ver a guerra para detestá-la, que nunca fui ao xilindró, e todavia não o estimo. Há coisas que se prejulgam, e as touradas estão nesse caso.

E querem saber por que detesto as touradas? Pensam que é por causa do homem? Ixe! é por causa do boi, unicamente do boi. Eu sou sócio (sentimentalmente falando) de todas as sociedades protetoras dos animais. O primeiro homem que se lembrou de criar uma sociedade protetora dos animais lavrou um grande tento em favor da humanidade; mostrou que este galo sem penas de Platão pode comer os outros galos seus colegas, mas não os quer afligir nem mortificar. Não digo que façamos nesta Corte uma sociedade protetora de animais; seria perder tempo. Em primeiro lugar, porque as ações não dariam dividendo, e ações que não dão dividendo... Em segundo lugar, haveria logo contra a sociedade uma confederação de carroceiros e brigadores de galos. Em último lugar, era ridículo. Pobre iniciador! Já estou a ver-lhe a cara larga e amarela, com que havia de 
ficar, quando visse o efeito da proposta! Pobre iniciador! Interessar-se por um burro! Naturalmente são primos? - Não; é uma maneira de chamar a atenção sobre si. - Há de ver que quer ser vereador da Câmara: está-se fazendo conhecido. - Um charlatão.

Pobre iniciador!

\section{Capítulo II}

Touradas e caridade pareciam ser duas coisas pouco compatíveis.

Pois não o foram esta semana última, fez-se uma corrida de touros com o fim de beneficiar necessitados.

O pessoal era de amadores, uns já peritos; outros novos; mas galhardos todos, e moços de fino trato. A concorrência, se não foi extraordinária, foi assim bastante numerosa.

E não a censuro, não; a caridade fazia dispensar a feroci... não, digo ferocidade; mas contarei uma pequena anedota. Conversava eu há dias com um amigo, grande amador de touradas, e homem de espírito, s'il en fut.

- Não imagines que são touradas como as de Espanha. As de Espanha são bárbaras, cruéis. Estas não têm nada disso.

- E entretanto...

- Assim, por exemplo, nas corridas de Espanha é uso matar o touro... Nesta não se mata o touro; irrita-se, ataca-se, esquiva-se, mas não se mata...

- Ah! Na Espanha, mata-se?

- Mata-se... E isso é que é bonito! Isso é que é comoção!...

Entenderam a chave da anedota? No fundo de cada amador de tourada inocente, há um amador de tourada espanhola. Começa-se por gostar de ver irritar o touro, e acaba-se gostando de o ver matar.

Repito: eu gosto simplesmente de o comer. É mais humano e mais higiênico. (cf. Machado de Assis, 2011, p.114-6; idem, 2009, p.175-7)

Machado de Assis, em sua crônica, evidencia ironicamente a defasagem das ideias que circulavam no Brasil em relação às que 
ele considerava as mais avançadas de sua época. Ele repete por três vezes, ao longo do parágrafo do primeiro trecho incluído no extrato acima, a designação "sociedade protetora dos animais", como se, pelo excesso e repetição, conseguisse ressaltar o vazio daquela instituição no contexto brasileiro. Nelson Aprobato Filho (2012, p.20) mostra que, nessa crônica, quando Machado de Assis menciona tal sociedade tinha em mente, muito provavelmente, a Royal Society for the Prevention of Cruelty to animals, fundada em Londres em 1824, assim como outros grupos similares fundados na Europa e nos Estados Unidos, a partir do modelo da Royal Society; mostra também que a "parceria sentimental" do cronista face às sociedades protetoras dos animais tem o objetivo de chamar a atenção para o vazio social.

Em um nível mais explícito, todas as críticas armadas pelo texto acentuam o absurdo e o ridículo que representaria, no Rio, a fundação de uma sociedade cujo objetivo fosse a proteção dos animais: as pessoas amaldiçoariam o fundador, por exemplo, desfazendo dela por sua ignorância ou atribuindo-lhe intenção escusa. Ao mesmo tempo, a "piedade" que o narrador da crônica lhe endereça, ainda uma vez em dose tripla (a expressão "Pobre iniciador" é repetida por três vezes, tal e qual a "sociedade protetora dos animais"), mostra que na realidade ele não está de acordo com a opinião corrente, o que desvela diante do leitor, imediatamente, a insuficiência da Opinião. Desse modo, o coro dos comuns torna-se, rapidamente, vítima da crônica.

$\mathrm{Na}$ segunda parte do texto citado, o narrador-cronista evoca a incompatibilidade entre touradas e caridade - "Touradas e caridade pareciam ser duas coisas pouco compatíveis. Pois não o foram esta semana última, fez-se uma corrida de touros com o fim de beneficiar necessitados" -, o que questiona o objetivo declarado da festa, a ação caritativa, assim como os próprios anúncios do evento que, aliás, não deixam saber claramente qual é a associação de beneficência à qual seriam endereçados os lucros com a tourada. Apoiando-se ainda no texto do anúncio, o narrador-cronista desnuda a ridícula exageração com que se descrevem a suntuosidade da festa e dos participantes, ou os cavalos mais bonitos, os touros mais bravos etc. Deveria ficar claro para o bom leitor da crônica que a valorização do suntuoso no 
anúncio procura esconder o horripilante (ver irritar, farpear, atacar o touro e, no fundo, desejar vê-lo ser morto).

Por fim, o prazer humano ao qual se costuma atribuir o qualitativo "sádico" é confundido com o gosto por esse tipo de espetáculo. Pelo método da maiêutica socrática, o narrador-cronista faz com que um dos personagens de sua crônica, "homme d'esprit, s'il en fut", confesse que ele pode vislumbrar a beleza e sentir emoção no momento em que se mata o animal, durante as touradas espanholas: "Mata-se... E isso é que é bonito! Isso é que é comoção!...". Primeira conclusão: crônica e anúncio reafirmam aquela relação espaço-temporal que os textos estabelecem entre si dentro do mesmo jornal, além de externamente, à maneira da hiperleitura.

Os touros voltariam à pena do cronista:

Faltavam-nos os touros. Os touros vieram, e com eles toda a fraseologia, a nova, a elegante, a longa fraseologia tauromáquica; enfim, veio o bandarilheiro Pontes. Não tive a honra de ver este cavalheiro, que os doutores da instituição proclamam artista de alta escala; mas ele pertence ao número das coisas, em que eu creio sem ver; digo mais, das coisas em que eu tanto mais creio, quanto menos avisto. Porque é de saber que, em relação a essa nobre diversão do espírito, eu sou nada menos que um patarata; nunca vi corridas de touros; provavelmente, não as verei jamais. Não é que me falte incentivo. Em primeiro lugar, possuo um amigo, espírito delicado, que as adora e frequenta; depois, sempre me há de lembrar Santo Agostinho. Conta o grande bispo que o seu amigo Alípio, seduzido a voltar ao anfiteatro, ali foi de olhos fechados, resoluto a não os abrir; mas o clamor das turbas e a curiosidade os abriram de novo e de uma vez, tão certo é que esses espetáculos de sangue alguma coisa têm que fascinam e arrastam o homem. Pode ser que algum dia também eu vá atirar lenços e charutos aos pés de algum bandarilheiro célebre; pode ser... [...] (Machado de Assis, 2008c, p.34)

Naquele 16 de junho de 1878, com o mesmo espírito de provocação da crônica de 15 de março de 1877, Machado cronista disse aos 
seus leitores "que farpear um touro ou esculpir o Moisés [de Michelangelo] é o mesmo fato intelectual" (ibidem, p.112). A seguir, vêm enunciadas as ideias já citadas da crônica de 1878, que se assemelham às de 1877: o amigo de fino espírito que ama as touradas ou as coisas nas quais o narrador-cronista crê sem ter tido necessidade de ver. $\mathrm{O}$ tema do prazer sádico do homem diante do sofrimento do animal reaparece também e a autoridade de Santo Agostinho é evocada para confirmar o argumento do cronista: a impossibilidade de dissociar a presença a um espetáculo violento (um combate entre gladiadores, no caso do bispo Alípio) da afirmação do gosto dissimulado por essa violência ou do prazer de a experimentar de alguma forma. Alguns anos mais tarde, no romance Quincas Borba, será por meio de Rubião que o narrador veiculará a mesma ideia, quando o herdeiro do filósofo de Barbacena assiste o enforcamento de um escravo:

$\mathrm{Na}$ esquina da Rua dos Ourives deteve-o um ajuntamento de pessoas, e um préstito singular. Um homem, judicialmente trajado, lia em voz alta um papel, a sentença. Havia mais o juiz, um padre, soldados, curiosos. Mas, as principais figuras eram dois pretos. Um deles, mediano, magro, tinha as mãos atadas, os olhos baixos, a cor fula, e levava uma corda enlaçada no pescoço; as pontas do baraço iam nas mãos de outro preto. Este outro olhava para a frente e tinha a cor fixa e retinta. Sustentava com galhardia a curiosidade pública. Lido o papel, o préstito seguiu pela Rua dos Ourives adiante; vinha do Aljube e ia para o Largo do Moura.

Rubião naturalmente ficou impressionado. Durante alguns segundos esteve como agora à escolha de um tílburi. Forças íntimas ofereciam-lhe o seu cavalo, umas que voltasse para trás ou descesse para ir aos seus negócios, outras que fosse ver enforcar o preto. [...]

Verdade é que o réu ainda não subira à forca, não o matariam de relance; sempre era tempo de fugir. E, dado que ficasse, por que não fecharia os olhos, como fez certo Alípio diante do espetáculo das feras? Note-se bem que Rubião nada sabia desse tal rapaz antigo e ignorava, não só que fechara os olhos, mas também que os abrira logo depois, devagarinho e curioso. (idem, 2008d, v.1. p.798) 
Nesse trecho do romance, a fina ironia do narrador desenha limites sutis, pois a incapacidade de escolha de Rubião, diante das forças íntimas que lhe ofereciam um cavalo e lhe sugeriam ao mesmo tempo ir cuidar de seus negócios ou ir ver enforcar o escravo, é apenas uma aparência. Diante do espetáculo de horror que se anunciava, entre partir e ficar, Rubião deixa-se estar, de modo que "o terror dissimulava a perversidade" (ibidem). Além disso, como na crônica, o mesmo exemplo de Alípio, prestes a assistir ao espetáculo de feras, é evocado, nesse caso com desvantagem para o personagem ficcional, a quem o narrador expõe, por sua ignorância. Dessa forma, o medo e a curiosidade do futuro bispo de Tagaste diante do espetáculo de luta entre animais e homens personifica-se em Rubião e, com ele, o juízo crítico de Santo Agostinho (Livro VI, cap. 8, 1999, p.156-7) a respeito de seu discípulo Alípio.

Da crônica ao conto, há outras histórias em que se torturam animais, alguns ratos, como aconteceria, em 1885, em "A causa secreta". Antes dele, em 13 de maio de 1883, o "Conto alexandrino" foi publicado nas páginas da Gazeta de Notícias, recolhido em livro por Machado de Assis em 1884 (Histórias sem data). Nessa história, Stroibus e Pítias, filósofos cipriotas, viajam à Alexandria para ali colocar em prática suas experiências. Habituados à metafísica, mas estendendo seu conhecimento à anatomia, "acham que descobriram o próprio alfabeto da moralidade" (Gledson in Machado de Assis, 1998, p.25). Ambos torturam ratos, extraindo deles sangue com o qual pretendiam provar que "[...] o sangue de rato, dado a beber a um homem", pode "fazer do homem um ratoneiro" (Machado de Assis, 2008d, v.2, p.386).

Nesse conto, a crítica tem reconhecido um dos textos em que Machado faz da Ciência matéria de ficção ou sua crítica ao exagerado entusiasmo pelo cientificismo da época, principalmente no que se refere à aplicação dos conceitos evolucionistas e positivistas à compreensão da sociedade humana. Especificamente em relação ao "Conto alexandrino", essa discussão pode ser fértil. No capítulo II do longo conto, o narrador assim nos descreve a "experiência": 
Stroibus engaiolava os ratos; depois, um a um, ia-os sujeitando ao ferro. Primeiro, atava uma tira de pano no focinho do paciente; em seguida, os pés; finalmente, cingia com um cordel as pernas e o pescoço do animal à tábua da operação. Isto feito, dava o primeiro talho no peito, com vagar, e com vagar ia enterrando o ferro até tocar o coração, porque era opinião dele que a morte instantânea corrompia o sangue e retirava-lhe o princípio. Hábil anatomista, operava com uma firmeza digna do propósito científico. Outro, menos destro, interromperia muita vez a tarefa, porque as contorções de dor e de agonia tornavam difícil o meneio do escalpelo; mas essa era justamente a superioridade de Stroibus: tinha o pulso magistral e prático. (ibidem, p.388)

Um trecho como esse deixa praticamente evidente uma vontade de provocar no leitor a aversão ao procedimento experimental em questão, por meio de uma aguda ironia em relação a certas práticas do cientificismo. Essa leitura é importante e poderia, ainda, levar a discutir de que maneira a literatura machadiana pensa contemporaneamente o progresso desenfreado da ciência que, em nome de sua verdade, não considera a alteridade, numa relação não estranha aos mecanismos de quase invisibilidade do outro nas relações de poder.

No caso desse conto, novamente, são os animais que ocupam o lugar dos oprimidos, para depois fazerem-no os homens: "Diziam os alexandrinos que os ratos celebraram esse caso aflitivo e doloroso [o fim de Stroibus e Pítias] com danças e festas, a que convidaram alguns cães, rolas, pavões e outros animais ameaçados de igual destino [...]" (ibidem, p.391). Porém, para além do animal, a situação seria a mesma para o negro, o estrangeiro, a criança ou o "louco", a natureza de cujo "desvio", neste último caso, também ocupava as cabeças da filosofia e medicina no século XIX (Foucault, 2005).

O conto acaba mal para Pítias e Stroibus que se tornam, ainda vivos, objetos de investigação anatômica. Globalmente, outra leitura possível, a partir disso, é que essa narrativa se situe no domínio do desvario e do prazer sádico e horripilante do homem frente à dor, ou, mais uma vez, tal e qual ocorreria em "A causa secreta", pode ser que 
a dor alheia coloque o leitor frente a personagens que desejam por meio do desejo do outro (Santiago, 2008, p.185).

Uma alternativa interpretativa abre-se diante da ideia de que "a obra não é jamais a mesma quando inscrita em formas distintas, ela carrega, a cada vez, um outro significado" (Chartier, 1999, p.72). Lidos, hoje em dia, somente no suporte material livro, os contos e crônicas machadianos, ainda que em edições anotadas, certamente recebem análises diferentes daquela que indica a leitura do texto inscrito na materialidade do veículo em que originalmente circulou. O público dos jornais, cada vez mais frequentemente a partir do final dos anos 1870, deparava-se com textos de desagradável leitura, como aquela da notícia que Machado de Assis comentou em sua crônica de 7 de julho de 1878, referindo-se ao sujeito que dera à luz a ossada de um feto em Caravelas. Diretamente citando o relato do profissional que atendeu o caso, ocorrido em uma das províncias do Império brasileiro, tem-se que

[...] F...., que V. deve conhecer, é um homem de 40 anos, e que nunca teve saúde. Além daquela fístula no nariz, tinha conscientemente dores atrozes sobre o peito e uma cor quase ictérica. Ultimamente foi para a cama sentindo uma dor agudíssima na região precordial, movimentos desordenados do coração [...]

Nestas condições chamaram-me; fui vê-lo e [...] ordenei um purgante.

Quando as dejeções começaram, vieram me dizer que o homem não tardava a morrer, pois que já estava deitando pedaços. Mandei que guardassem as matérias fecais para examinar.

De fato guardaram; e quando fui vê-las, notei que havia muitos corpos sólidos; disse à família que os extraísse dali, que os lavasse e me desse.

Assim ela fez e eu reconheci a ossada de um feto.[... $]^{10}$

10 Jornal do Commercio, “Gazetilha”, $1^{\circ}$ jul. 1878, p.2, col. 2. 
Como seu viu em "Primeiras palavras" (Capítulo 1), ao comentar o último relato, o cronista Machado de Assis reproduziu o conteúdo em linguagem que traz termos técnicos, acentuando a sua incredibilidade. Frente à estranha notícia e ao caso médico que ela veicula, até mesmos as histórias orais passadas de geração em geração ganham estatuto de possibilidade de verdade ("não há nada que [...] possa dominar o sucesso máximo, o sujeito que em Caravelas [...] na Bahia, deu à luz uma criança. Quando eu era pequeno, ouvia dizer que o galo, chegando à velhice, punha ovos, como as galinhas; [...] já agora devo crer que o conto não era da carocha, senão pura e real verdade”) (Machado de Assis, 2008c, p.145). Retoricamente, a referência à narrativa oral como critério de credibilidade para a publicação do Jornal do Commercio inverte o efeito e desacredita imediata e ironicamente a notícia que trazia o relato de um cientista, o que coloca mais uma vez em xeque o estatuto de verdade da notícia e, por metonímia, do próprio relato científico. Reproduz-se, aliás, na citada crônica machadiana de 7 de julho de 1878, em eco, toda a terminologia médica da notícia, como paródia à autoridade do discurso científico ("precordial", "movimentos desordenados do coração", "dispneia", "forte edemacia”). ${ }^{11}$

A discussão machadiana evoca diretamente a questão da ficção na Poética da escrita da imprensa na qual se informa, instrui, narra, diverte-se e se publica a ficção, tudo junto no mesmo espaço, mas sem que os traços que recortam o branco da folha em caixilhos realmente cheguem a separar nitidamente todos esses regimes discursivos (estruturados sobre uma escala que vai da referencialidade à ficção), bem como seus efeitos de leitura. A crônica de variedades debate com o leitor, recortando do relato noticiado pela "Gazetilha" o incrível, o paradoxal, o notável aos olhos narrador-cronista, atitude

11 Entre 1873 e 1874, Machado de Assis traduziu para a Instrução pública uma série de conferências do Dr. F. Gallard, intituladas "Higiene para uso dos mestres-escola”. Hélio Guimarães (2015, p.337), em resenha sobre volume de textos inéditos organizado por Mauro Rosso (Machado de Assis, 2014), vê nesses textos uma possível matriz "para o modo distanciado e frio com o qual os narradores machadianos tratam de situações extremas e aflitivas". 
que evidencia a situação do leitor: ele crê ou não crê naquilo que lê? Nesse ponto, uma observação pertinente é que existem pactos de leitura implícitos às formas jornalísticas (Thérenty, 2007, p.17), os quais agem permissivamente na consideração e aceitação da variação gradual entre "verdade" (ciência) e ficção, por um lado, e informação e entretenimento (imaginação) por outro, quer seja no noticiário do jornal, quer seja no texto mais literariamente elaborado da crônica, tudo sob a forma narrativa. Em Machado, a sempre presente autorreferencialidade faz com que a crônica pense sua escrita, sua relação com o veículo e com os leitores, num procedimento nada estranho à novidade da ficção machadiana.

Do relato médico em forma de notícia passa-se a um texto misto entre relatório de experiência e ata de reunião, publicada em vários jornais da corte à mesma época, nas seções correspondentes às "Ciências":

Primeira experiência. - Em um porquinho-da-índia adulto, foi praticada uma incisão de 2 centímetros de extensão na parte interna da coxa esquerda entre a pele e o tecido celular. Algumas gotas de sangue são recolhidas da ferida e postas em um vidro apropriado para ser observado ao microscópio pelo Dr. Gama Lobo. Uma flecha envenenada da grossura de uma vareta de chapéu de sol, e pontiaguda é posta em contato da ferida por espaço de 30 segundos marcados a relógio de segundos independentes.

Solto o animal, ainda corre; 1 minuto e 35 segundos depois, para, tem paralisados os quartos posteriores, as pupilas dilatadas, manifesta ligeiros movimentos convulsivos parciais, as orelhas apenas acusam sensibilidade, a cabeça pende para um lado, completa resolução de todos os músculos, insensibilidade geral, resfriamento e finalmente a morte. $[\ldots] .^{12}$

As experiências do médico João Barbosa Rodrigues para encontrar um antídoto para o curare (ou urary), veneno paralisante que

12 Jornal do Commercio, Ciências, 6 jul. 1878, p.2. 
os índios usavam nas pontas de suas flechas, foram publicadas por dias repetidos em todos os jornais de grande circulação da corte. No texto citado no jornal, informa-se que a reunião científica prosseguiu durante todo o dia, tendo como cobaias ratos e bichos um pouco maiores (como o porquinho-da-índia), tão "assustadora”, portanto, quanto as descritas pelo "Conto alexandrino". ${ }^{13}$ No entanto, temos aí um relatório cuja divulgação era não só esperada, mas também aplaudida pelos jornais.

Frente a isso, é impossível deixar de perceber que o leitor da época estava habituado a, em nome da divulgação científica, ler a descrição miúda de algumas práticas médicas experimentais. Nesse caso, qual é o grau de horror que a recriação de uma experiência de vivissecção de ratos e cobaias produz no ambiente de ficção? Se, naquele caso, a incisão toca o coração, aqui ela continua pela introdução da seta pontiaguda e envenenada na coxa do animal, que corre até morrer depois de solto, de modo que não há de ser nas "minúcias" que um caso se tornará mais terrível que o outro. $\mathrm{Na}$ verdade, como o narrador da ficção machadiana aproveita ironicamente o discurso científico, ele parece deslocado no ambiente ficcional e, por extensão, parodia a naturalidade com que é expresso no espaço do relato do "real".

Fica assim evidenciado que a circulação das formas textuais se fazia constantemente no "hipertexto" do periódico cotidiano, criando uma referencialidade e "literaridade" deslizantes, em que as transferências entre escrita literária (aí compreendida a ficcional) e jornalística são grandes e constantes. Pelo olhar do "verdadeiro" e do referencial, Sarah Mombert (2011, p.811, tradução nossa) aponta a mesma via de mão dupla:

13 Daniela Silveira (2010) estudou as coletâneas de contos Papéis avulsos e Histórias sem data, pensando em seu critério de organização (ciência e literatura), além de observar que Machado de Assis aproveita-se de notícias veiculadas pelos jornais da época, propondo leituras interligadas dos textos nas colunas dos jornais. Em 2008, nosso artigo "Antes do livro, o jornal” (Granja, 2009), que deu origem a este capítulo, havia proposto uma discussão mais estética que ideológico-cultural da questão. 
[A questão do verdadeiro] é consubstancial à natureza referencial da escrita jornalística. Se em sua ambição de dizer o mundo real o jornal coloca em primeiro plano o caráter verídico de seu discurso, ele mostra ao mesmo tempo o compromisso representado por essa exigência de verdade, e confessa a tentação de atravessar as fronteiras, em particular aquela que separa a informação verídica da ficção. O modo de leitura do jornal depende largamente dessa questão: os fatos relatados são verídicos ou ficcionais (até mesmo enganadores)? Sua função é informar com lealdade, alimentar o imaginário de um leitor ávido de distração ou persuadir por meio de um discurso engajado? ${ }^{14}$

Fica também evidente que o texto machadiano se nutre da extrema consciência de seu autor sobre os efeitos tipográficos, poéticos, retóricos e ideológicos do suporte sobre o qual se forma e ao qual se conforma. No final dos anos 1870 e início dos anos 1880, se a crônica mostra as contradições do modo de leitura do jornal, a ficção absorve plástica e parodicamente a Poética constitutiva daquele universo textual. Levando seus questionamentos ao paroxismo ou criando esteticamente por meio da leitura dos modos de operar textos e discursos que lhe eram contemporâneos, Machado de Assis, esse escritor monstruoso, afeito a construir literariamente em desproporções, usou como fonte para a modernidade de sua escrita literária as possibilidades todas que lhe ofereceram a escrita do folhetim-variedades dominical, assim como a variadíssima gama de formas que a crônica e o próprio jornal admitiam.

14 "[La question du vrai] est consubistantielle à la nature référencielle de l'écriture journalistique. Si, dans son ambition à dire le monde réel, le journal met en avant le caractère vérifdique de son discours, il désigne en même temps la contrainte représentée par cette exigence de vérité, et avoue la tentation d'en franchir les frontières en particulie celle qui sépare l'information véridique de la fiction. Le mode de lecture du journal dépend largement de cette question: les faits relatés sont-ils véridiques ou ficitifs (voire mensongers)? Leur fonction est-elle d'informer loyalelemnt, de nourrir l'imaginaire d'un lecteur avide de distraction ou de persuader par un discours engagé?". 


\section{Capítulos de uma revolução: Memórias Póstumas de Brás Cubas}

A revolução causada por Memórias Póstumas de Brás Cubas na Literatura Brasileira tem produzido milhares de páginas de debates. Há já quase trinta anos, Roberto Schwarz (1990, p.16) retomou assim essa discussão:

A estridência, os artifícios numerosos e a vontade de chamar a atenção dominam o começo das Memórias Póstumas de Brás Cubas (1880).

$[\ldots]$

A persistência na afronta, sem a qual as Memórias ficariam privadas de seu ritmo próprio, funciona como um requisito técnico. Para cumpri-lo o narrador a todo momento invade a cena e "perturba" o curso do romance. Essas intromissões, que alguma regra sempre infringem, são o recurso machadiano mais saliente e famoso. A crítica as tratou como um traço psicológico do Autor, deficiência narrativa, superioridade de espírito, empréstimo inglês, metalinguagem, nada disso estando errado.

Todas as perspectivas que explicam os artifícios da prosa das $\mathrm{Me}$ mórias parecem ser, segundo o crítico, à primeira vista, complementares na compreensão dos procedimentos narrativos do romance. No ensaio do próprio Schwarz, a diferença é vista como forma, regra de composição narrativa ou estilização de uma conduta própria à classe dominante (ibidem, p.16-7).

Entre várias outras, leituras viriam se juntar ao debate sobre as Memórias Póstumas nas últimas duas décadas, tendo sido o romance compreendido como tendo incorporado à narrativa o problema da recepção, em variados níveis, desde a textualização dos leitores comuns e críticos até a indicação não pedagógica dos significados a extrair da leitura tão pouco palatável (Guimarães, 2004, p.17593); como respondendo a uma "forma shandiana", caracterizada pela presença constante e caprichosa do narrador, por uma técnica 
de composição difusa e livre, pela interpenetração do riso e da melancolia e pela subjetivação radical do tempo do espaço (as viagens) (Rouanet, 2007); como escrita do tragicômico que perpassa todos os romances, em continuidade e progressão (Souza, 2006); como resultado de uma verossimilhança bifocal que possibilita a descrição contraditória da alma humana (Bosi, 2006, p.7-52) a partir de uma perspectiva fenomenológica, que coloca em evidência "questões estéticas, referentes à recepção do texto como uma obra de arte, à riqueza de sua mensagem e aos valores humanos por ela comunicados" (Dixon, 2009, p.14). Machado de Assis e sua obra são também compreendidos como um melhor conciliador entre o nacional e universal a partir de suas experiências literárias e teatrais do início dos anos 1870 (Faria, 2011, p.110-26), como um escritor que passou por uma mudança ideológica na mesma década (Schwarz, 1990) ou, ainda, profunda crise estética, mais longa e intensa do que se pôde avaliar até há poucos anos (Gledson, 2011, p.29-50; Gledson; Granja, 2008, p.119-29).

Retomando a ideia do escritor monstruoso, a obra de Machado de Assis não poderia suscitar menor nem menos amplo debate crítico. Complementarmente à incorporação do jornalismo à literatura (Granja, 2000), a sua longeva colaboração para os periódicos é aqui entendida como um caminho para a novidade literária, pela profunda compreensão dos suportes/veículos em que o jornalista-escritor atuou, aproveitando crítica e parodicamente os seus recursos poéticos, na continuidade. Afinal, Machado de Assis só abandonaria o jornalismo literário e a publicação da ficção nos jornais já avançados os anos 1890, quando se tornara um escritor mais do que consagrado no embrionário campo literário brasileiro, para cuja edificação vinha contribuindo e contribuiria, naqueles tardios anos do século XIX, como fundador e presidente da instituição cultivadora da literatura nacional, a Academia Brasileira de Letras.

Em relação às várias formas de referência à tradição literária, por exemplo, cujo uso é frequente em toda obra de Machado de Assis, mas especialmente em suas crônicas, os efeitos plásticos consequentes do uso espacial da página do jornal (caixilhos) acentuam o caráter 
polêmico desse tipo de referência textual, como se viu. Isso quer dizer que já a visualização da página do jornal permitia ao leitor a tomada de consciência a respeito do conteúdo crítico do texto, o que mostra o quão estruturadora uma citação poderia ser para a crítica do folhetim. Constituindo-se tipograficamente de forma mais arejada, a citação é arranjada, na terminologia jornalística moderna, como olho do texto, encaixado no bloco pesado da coluna, o que chama a atenção sobre si e para dentro dela, tal e qual na quinta coluna da imagem a seguir.

Figura 13 - "Ao Acaso", de Machado de Assis. Diário do Rio de Janeiro, "Folhetim", 14 de agosto de 1864, rodapé, p.1, cols., 1-7

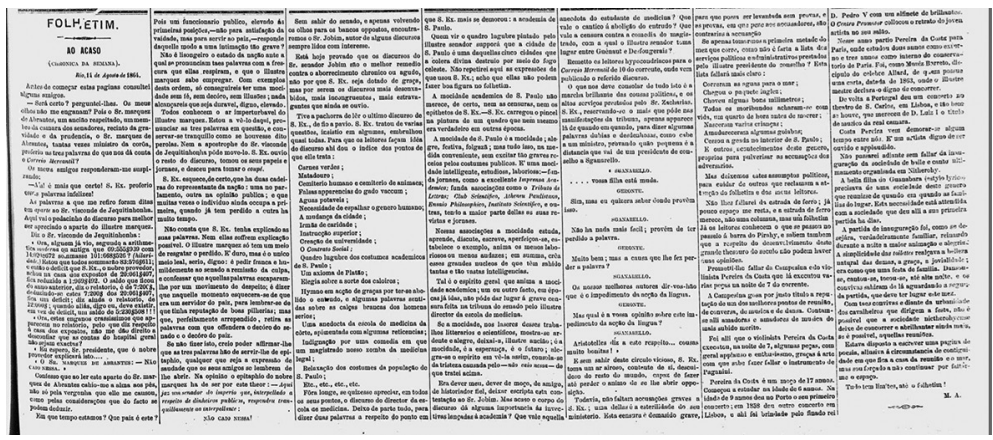

Fonte: Imagens adquiridas junto à Biblioteca Nacional do Rio de Janeiro pelo Projeto Temático Fapesp A circulação transatlântica dos impressos.

Na crônica de 14 de agosto de 1864, os comentários do narrador machadiano estiveram voltados à prática política parlamentar, criticamente centrados na habilidade de elocução dos políticos da época. Ela assim se inicia:

Antes de começar estas páginas consultei alguns amigos.

- Será certo? perguntei-lhes. Os meus olhos não me enganam? Pois o Sr. Marquês de Abrantes, um ancião respeitado, um membro da câmara dos senadores, recinto da gravidade e da prudência, Sr. marquês de Abrantes, tantas vezes ministro da Coroa, proferiu as três palavras de que nos dá conta o Correio Mercantil? 
No decorrer do texto machadiano, vê-se que o marquês de Abrantes proferira no Senado a frase "Não caio nessa", posteriormente publicada pelo Correio Mercantil, quando da transcrição desse discurso que ocorrera no parlamento. Esse é o contexto amplo do comentário machadiano, mas o que interessa para o argumento é observar que a quinta coluna da crônica em questão traz uma relativamente longa citação do Le Médecin malgré lui, de Molière, que informa ao leitor, já visualmente, qual era o tom dos comentários do cronista a respeito do rumo das coisas políticas e dos debates no Senado Imperial ou o do “presente como comédia” (Granja, 2000, p.72-90, 102):

O que vem anos consolar de tudo isto é a marcha brilhante das cousas políticas, e os altos serviços prestados pelo Sr. Zacarias. S. Ex., reservando-se o mais que pôde nas manifestações da tribuna, apenas aparece lá de quando em quando, para dizer algumas palavras dúbias e desdenhosas, como cabe a um ministro, provando quão pequena é a distância que vai de um presidente de conselho a Sganarello.

SGANARELLO - ...vossa filha está muda.

GERONTE - Sim, mas eu quisera saber d'onde provém isso.

SGANARELLO - Não há nada mais fácil; provém de ter perdido a palavra.

GERONTE - Muito bem, mas a causa que lhe fez perder a palavra?

SGANARELLO - Os nossos melhores autores dir-vos-ão queé impedimento da ação da língua.

GERONTE - Mas qual vossa opinião sobre esse impedimento da ação da língua?

SGANARELLO - Aristóteles diz a esse respeito... coisas muito bonitas! $!^{15}$

Ao inserir o trecho da comédia de Molière, em que Geronte e Sganarelle discutem a mudez de Lucinde, o narrador traz para o

15 "Ao Acaso", de Machado de Assis. Diário do Rio de Janeiro, "Folhetim", 14 ago. 1864, rodapé, p.1, cols., 1-7. 
mundo da crônica toda uma série de referências irônicas deflagradas pelo contexto primeiro da ocorrência da citação. O leitor, que conhece Molière, ao passar os olhos pela quinta coluna do rodapé/ crônica, tal e qual na crônica francesa de Théophile Gautier (conferir "Outra contribuição da crônica" no Capítulo 1 deste livro), já tem de antemão à leitura o efeito crítico de toda a referência política crônica. A partir daí, pensando na ficção que se apoia sobre a matriz do jornalismo, o mesmo efeito de intensificação será incorporado aos procedimentos da ficção e aos desabusos do célebre romance Memórias Póstumas de Brás Cubas, em termos textuais e plásticos.

Ao longo do século XIX no Brasil, o romance-folhetim, principalmente traduzido das páginas dos jornais ou dos volumes franceses, esteve presente no rodapé dos periódicos brasileiros de forma significativa. "Por que o sucesso [do romance-folhetim] em longínquas plagas, onde não existe ainda a cidade grande, de uma fórmula tão ligada a certo momento social francês, europeu [?]”, perguntou-se anteriormente Marlyse Meyer (1996, p.33). Ou seja, na França, mas também no Brasil, a fórmula inventada por Émile de Girardin para o La Presse, com objetivo de expandir comercialmente o jornal, teve sucesso, pois já respondia a hábitos adquiridos de leitura ou audição da ficção. Em Alexandre Dumas, Meyer resume a técnica do romance-folhetim praticado nos jornais: "Dumas [...] mergulha o leitor in media res, diálogos vivos, personagens tipificados, e tem senso do corte de capítulo. Não é de espantar que a boa forma folhetinesca tenha nascido das mãos de um homem de teatro" (ibidem, p.60).

Expandindo a observação de Marlyse Meyer, temos que nas Memórias Póstumas, o leitor é, mais do que "jogado in media res", deixado a ver navios, sem o porto seguro dos pactos ficcionais habituais do romance.

Segundo ponto, o romance desfaz a teatralidade característica da narrativa brasileira ${ }^{16}$ e os diálogos vivos tornam-se oblíquos: en-

16 Antonio Candido (1981, v.2, p.136-45), em "O honrado e facundo Joaquim Manuel de Macedo", observa o impulso tagarela e muito conversador de 
quanto um almocreve preenche o espaço sonoro com generalidades, aquele que escuta, e posto que escuta, reduz a recompensa de algumas moedas de ouro a apenas uma de prata.

Em terceiro lugar, Machado de Assis, homem de seu tempo e, sem dúvida, do teatro, ${ }^{17}$ criou novidades por meio de uma nova forma de tipificação das personagens. Alfredo Bosi (2006, p.9), debatendo com Roberto Schwarz, deixa claro que associar Brás Cubas ao discurso representativo diminui a singularidade do romance, pois "não há neste Machado maduro um espelho do mundo dissociado do olhar pensativo, como não há desenho de um quadro sem a projeção de alguma perspectiva". Pode-se pensar, em termos de Poética, que a experiência do jornal decalca a personagem tipificada tão em evidência no folhetim (e nos hábitos dos leitores), mas sem as estripulias e os valores absolutos de condes, aventureiros ou mosqueteiros, preenchendo o desenho copiado de uma reflexão exterior ao indivíduo, tipo ou sujeito. Nesse caso, fica e não fica o leitor em sua zona de constância, enquanto o personagem transita de uma perspectiva realista para o moderno desconforto diante do mundo, figurado pelo próprio descompasso da construção do personagem, plasticamente paródica, além de filosófica e representativa.

A quarta questão une o homem de teatro ao jornalista, sob o signo do corte, que faz a transição do folhetim e o acabamento das cenas do teatro. Nas Memórias, esse recurso dual, misto de fechamento e transição, é valorizado e utilizado em seu caráter metanarrativo, agora figurando parodicamente os hábitos de leitura dos romances; uma vez em livro, o corte trazido à cena desestabiliza o fluxo da narrativa. ${ }^{18}$

Macedo, reconhecendo também que a tendência do romance brasileiro do XIX ao colóquio tem raízes na experiência do público com o teatro.

17 Como mostra o trabalho de João Roberto Faria (cf. Machado de Assis, 2008a), a contribuição de Machado de Assis para o teatro e a reflexão sobre ele é vasta. Homem imerso no debate cultural de seu tempo, teve alto grau de envolvimento com o teatro, desde a juventude até a velhice.

18 Na linha da "solicitação do livro" (Baptista, 1998), alguns trabalhos têm lido no romance machadiano a performatividade da narrativa. Segundo Daniela Portela (2008, p.88-103), existe nas Memórias Póstumas a teatralização do processo de 
Sem dúvida, como A mão e a luva, Helena e Iaiá Garcia, e até mesmo alguns contos, as Memórias Póstumas de Brás Cubas já foram concebidas enquanto romance seriado para ocupar o livro, seguidamente às páginas dos periódicos. Mostram-no a republicação em livro pela Typographia Nacional, menos de um ano depois de seu aparecimento nas páginas da Revista Brasileira, entre 15 de março e 15 de dezembro de 1880.

Samuel Titan Junior (2009, p.144-9), em um artigo muito esclarecedor sobre a relação entre o romance e o seu veículo primeiro de circulação, observou, entre outras coisas, que a revista em questão não distinguia graficamente os textos ou seções, propondo hipóteses sobre a circularidade dos conteúdos e que os capítulos eram publicados em grupos de mais ou menos nove textos.

Já Regina Zilberman, que também se dedicou a uma análise comparativa das versões do romance na revista e no livro, analisou detalhadamente várias questões relativas ao romance publicado quinzenalmente e logo reunido em volume, apontando as mudanças no capítulo de abertura, no prólogo, na dedicatória, e analisando ainda o "discurso do método" presente nos nove primeiro capítulos, publicados no número de 15 de março de 1880, no terceiro tomo da Revista. Zilberman (2012, p.53-4), no capítulo "'Minha Theoria das Edições Humanas’ - Memórias Póstumas de Brás Cubas e a Poética de Machado de Assis", argumenta que a primeira versão que possuímos do romance, a da Revista Brasileira, detém o estatuto de fonte primária, e apresenta interessantes motivações e consequências

produção do livro e solicitação constante do leitor a confirmar os passos da escrita e fabulação. Além disso, a própria leitura do livro seria performática, figurando a manipulação concreta das páginas do livro. Segundo Antonio Silva (2008, p.46-50), a leitura dos capítulos curtos das $M P B C$ seria performática do jornal, e o texto incorporou técnicas de apresentação jornalística e experimentou outro modo de acesso ao romance, oferecido a um leitor habituado à leitura do folhetim e à crônica. Sérgio Motta (2006, p.15-68) mostra como o livro escrito por Brás Cubas seria performático de sua morte, à medida que figura a própria campa do defunto-autor. Não posso deixar de observar que sendo os três autores (Motta, Silva e Portela) colegas professores da Unesp ou formados pelo Ibilce-Unesp, devo também ao diálogo e convivência com eles a leitura que apresento neste livro. 
dessa leitura comparativa, inclusive a ideia de uma Poética de Machado de Assis, escrita nas Memórias Póstumas de Brás Cubas, que superaram a estética romântica e colocaram a "ficção nacional da trilha da maturidade". Ela afirma também que as "Memórias Póstumas suscitam a investigação para além do seu texto final" e que "o cotejo das versões é revelador porque sugere observações sobre o processo de criação do escritor", bem como "conclusões sobre o modo como o romancista lia a si mesmo" (ibidem, p.54).

Posteriormente a tais considerações, na discussão deste livro, os capítulos e cortes aparecem como protagonistas, em mais uma leitura da grande intimidade que a escrita de Machado de Assis tinha com os suportes periódicos, aproveitando-se do efeito que produziu o uso (e abuso) dos cortes no romance-folhetim, em folhas brasileiras. Um quadro completo da distribuição dos capítulos no romance, tanto no livro quanto na revista, introduz os vários usos do corte e dos capítulos.

Quadro 1 - Memórias Póstumas de Brás Cubas - distribuição dos capítulos.

\begin{tabular}{|c|c|c|}
\hline $\begin{array}{c}\text { Data de publicação } \\
\text { na Revista Brasileira } \\
\text { (1880) }\end{array}$ & $\begin{array}{l}\text { Capítulos (numeração } \\
\text { do capítulo em livro) }\end{array}$ & Nomes dos capítulos \\
\hline Tomo III-15 de março & $\begin{array}{l}\text { Dedicatória e capítulos } \\
\text { I a IX }\end{array}$ & $\begin{array}{l}\text { De "Óbito do autor" } \\
\text { a "Transição" }\end{array}$ \\
\hline $\begin{array}{l}\text { Tomo III }-1^{\circ} \text { de abril } \\
\text { de } 1880\end{array}$ & Capítulos X a XIV & $\begin{array}{l}\text { "Naquele dia..." a "O } \\
\text { primeiro beijo" }\end{array}$ \\
\hline Tomo IV - 30 de abril & $\begin{array}{l}\text { Capítulos XV a XXIII } \\
\text { Observação: suprimiu o } \\
\text { capítulo "Comoção" }\end{array}$ & $\begin{array}{l}\text { "Marcela" a "Volta ao } \\
\text { Rio" Termina com "não } \\
\text { nos alonguemos nesse } \\
\text { capítulo" }\end{array}$ \\
\hline Tomo IV $-1^{\circ}$ de maio & Capítulos XXIV a XXIX & $\begin{array}{l}\text { "Triste, mas curto" a } \\
\text { "Contanto que" }\end{array}$ \\
\hline Tomo IV - 15 de maio & $\begin{array}{l}\text { Capítulos XXX a } \\
\text { XXXV }\end{array}$ & $\begin{array}{l}\text { "A visita" até "A uma } \\
\text { alma sensível" }\end{array}$ \\
\hline Tomo IV $-1^{\circ}$ de junho & $\begin{array}{l}\text { Capítulos XXXVI a } \\
\text { XLIII }\end{array}$ & $\begin{array}{l}\text { "O c a minho de } \\
\text { Damasco" a "Que esca- } \\
\text { pou a Aristóteles" }\end{array}$ \\
\hline
\end{tabular}




\begin{tabular}{|c|c|c|}
\hline $\begin{array}{c}\text { Data de publicação } \\
\text { na Revista Brasileira } \\
(1880)\end{array}$ & $\begin{array}{l}\text { Capítulos (numeração } \\
\text { do capítulo em livro) }\end{array}$ & Nomes dos capítulos \\
\hline Tomo V $-1^{\circ}$ de julho & Capítulos XLIV a LIII & $\begin{array}{l}\text { "Marquesa, porque eu } \\
\text { serei marquês" a "O } \\
\text { embrulho misterioso" }\end{array}$ \\
\hline Tomo V - 15 de julho & $\begin{array}{l}\text { Capítulos LIV a LXI } \\
\text { Observação: suprimiu } \\
\text { o capítulo "De como } \\
\text { o autor não achando } \\
\text { denominação para este } \\
\text { capítulo, se limita a } \\
\text { escrevê-lo" }\end{array}$ & “......" a "Um projeto" \\
\hline Tomo V $-1^{\circ}$ de agosto & Capítulos LXII a LXX & $\begin{array}{l}\text { "O travesseiro" a "Dona } \\
\text { Plácida" }\end{array}$ \\
\hline $\begin{array}{l}\text { Tomo } V-15 \mathrm{de} \\
\text { agosto }\end{array}$ & $\begin{array}{l}\text { Capítulos LXXI a LXX- } \\
\text { XIII }\end{array}$ & $\begin{array}{l}\text { "O senão do livro" a } \\
\text { "13" }\end{array}$ \\
\hline $\begin{array}{l}\text { Tomo } V \text { - não tem } \\
\text { data, mas provavel- } \\
\text { mente } 1^{\circ} \text { de setembro }\end{array}$ & $\begin{array}{l}\text { Capítulos LXXXIV a } \\
\text { XC }\end{array}$ & $\begin{array}{l}\text { "O conflito" a "O velho } \\
\text { colóquio de Adão e } \\
\text { Caim" }\end{array}$ \\
\hline $\begin{array}{l}\text { Tomo V }-15 \mathrm{de} \\
\text { setembro }\end{array}$ & Capítulos XCI a XCIX & $\begin{array}{l}\text { "Uma carta extraordiná- } \\
\text { ria" a "Na plateia" }\end{array}$ \\
\hline $\begin{array}{l}\text { Tomo VI - não tem } \\
\text { data, provavelmente } 1^{\circ} \\
\text { de outubro }\end{array}$ & Capítulos CI a CIX & $\begin{array}{l}\text { "O caso provável" a "O } \\
\text { filósofo" }\end{array}$ \\
\hline $\begin{array}{l}\text { Tomo VI - } 15 \mathrm{de} \\
\text { outubro }\end{array}$ & Capítulos CX a CXXIII & $\begin{array}{l}\text { "31" a "O verdadeiro } \\
\text { Cotrim" }\end{array}$ \\
\hline $\begin{array}{l}\text { Tomo VI }-1^{\circ} \mathrm{de} \\
\text { novembro }\end{array}$ & $\begin{array}{l}\text { Capítulos CXXIV a } \\
\text { CXXXVIII }\end{array}$ & $\begin{array}{l}\text { "Vá de intermédio" a "A } \\
\text { um crítico" }\end{array}$ \\
\hline $\begin{array}{l}\text { Tomo VI }-1^{\circ} \mathrm{de} \\
\text { dezembro }\end{array}$ & $\begin{array}{l}\text { Capítulos CXXXIX a } \\
\text { CXLIX }\end{array}$ & $\begin{array}{l}\text { "De como não fui Minis- } \\
\text { tro de Estado" a "Teoria } \\
\text { do Benefício" }\end{array}$ \\
\hline $\begin{array}{l}\text { Tomo VI - } 15 \mathrm{de} \\
\text { dezembro }\end{array}$ & Capítulos CL a CLX & $\begin{array}{l}\text { "Rotação e translação" } \\
\text { a "Das negativas" }\end{array}$ \\
\hline
\end{tabular}

Fontes: Revista Brasileira, março a dezembro de 1880, e primeira edição em livro.

Como ilustra o Quadro 1, na passagem da revista ao livro, Machado de Assis suprimiu dois capítulos metanarrativos, nenhum deles de transição, "Comoção" e "De como o autor não achando denominação para este capítulo, se limita a escrevê-lo”. Embora não se possa generalizar o procedimento, alguns dos capítulos 
que encerram grupos quinzenais são metanarrativos. É o caso de "Transição" (capítulo IX), "Volta ao Rio" (capítulo XXIII) e "Que escapou a Aristóteles" (capítulo XLIII). Entre eles, "Transição”, fulcro desta argumentação, será mais analisado adiante; no capítulo XLIII, tudo é pilhéria e nada de realmente novo escapou a Aristóteles; "Volta o Rio" apresenta um forte interesse na medida em que encerra uma sequência de oito capítulos nos quais há uma enorme aceleração do tempo (dos amores por Marcela até a volta ao Rio depois da viagem à Europa, obtenção do grau de bacharel e boa vida no velho continente). O último parágrafo desse capítulo vem reproduzido a seguir:

Vim... Mas, não; não nos alonguemos nesse capítulo. Às vezes, esqueço-me de escrever; a pena vai comendo papel, com grave prejuízo meu, que sou autor. Capítulos compridos quadram melhor a leitores pesadões e nós não somos um público in-fólio, mas in-12o, pouco texto, larga margem, tipo elegante, corte dourado e vinhetas, principalmente vinhetas... não, não nos alonguemos nesse capítulo. (Machado de Assis, 2008d, v.1, p.655-6)

A repetição de "não, não nos alonguemos nesse capítulo", que praticamente inicia e encerra o parágrafo de transição entre quinzenas, retoma o encurtamento do tempo da narrativa promovido pelo grupo de capítulos publicado em 30 de abril de 1880. É como se o autor ficcional, que se recusa displicentemente a descrever o seu retorno ao Rio de Janeiro, colocando em xeque a sua própria posição autoral, reiterasse a aceleração temporal pela repetição.

Nesse caso, ele transfere para a composição plástica dessas frases no trecho citado e para a própria composição da edição luxuosa (In-12, pouco texto, larga margem etc.) as formas de promover a aceleração e colocar em evidência o fato de que não se esmiuçará justamente a parte mais folhetinesca da vida do cavalheiro: seus picantes amores da juventude (longe das vistas paternas), as aventuras de estudante abastado em Coimbra e de turista pela Europa. Ou seja, por meio desses procedimentos, decalca-se o tipo folhetinesco, que 
permanece sulcado pela elisão máxima do enredo, e coloca-se em evidência não apenas o narrador/autor, mas a materialidade plástica e composicional da personagem e do livro, com os efeitos todos que se podem auferir desse novo protagonismo dos elementos.

Nessa mesma linha, há figuras em baixo relevo no capítulo "Contanto que" (XXVIII), final do grupo de 1o de maio 1880, que termina com a imagem daquele chocalho do amor da nomeada a se agitar diante do relativamente jovem Brás Cubas, ${ }^{19}$ e reafirma os dois endereçamentos narrativos do romance, aos graves e aos frívolos. Nesse novo capítulo de transição, o pai de Brás Cubas incita-o a uma candidatura à vida política e a aceitar Virgília como noiva. Está-se diante de um primeiro diálogo entre um pai e seu filho, em que o mais experiente pretende fazer subir o mais proximamente possível ao lugar de medalhão. No caso das Memórias, o "contanto que" é a solução para ambos os homens: Brás se recusa à duplicidade de tarefas e o pai admite a carreira solo, desde que ele "tema a obscuridade".

Na quinzena seguinte está situado o grupo de capítulos que narram o episódio polêmico do envolvimento entre Brás Cubas e Eugênia, ao fim do qual a expectativa de amor romântico (para agradar os leitores frívolos) é quebrada, assim como, pelo tratamento que se dá à questão, a gente grave também é duplamente desapontada: pelo comportamento vil em relação à moça e à narrativa do episódio, que castiga as almas sensíveis; pelo ridículo imediatismo de Brás ao aceitar o conselho do pai, "fugir ao ínfimo", já que, no global, não conseguirá fazê-lo, o que o episódio da Tijuca prenuncia. O tipo decalcado é, como se disse, sulcado; seus contornos são reforçados com a pena da galhofa; a figura que resta é preenchida com material que não quadra bem à composição ou à tinta da melancolia.

Invertendo a direção, vários dos capítulos de abertura dos grupos são trabalhados de forma a realçar a pontas da gangorra. ${ }^{20}$ Assim, o capítulo LIII, nomeado “.......", inicia a oitava quinzena, em que se

19 Para uma análise do chocalho como nucelar à narrativa das Memórias, conferir Paul Dixon (2009).

20 Sobre a estrutura oscilante, segundo Paul Dixon (2009, p.149), o chocalho "funciona como uma chave dos fenômenos centrais do romance". 
retoma o caso da meia-dobra encontrada por Brás e devolvida com alarde; ou, ainda, na décima semana, o autor arrepende-se do livro ("O senão do livro", capítulo LXXI), explicando a seu leitor, na retomada da narrativa, que "o livro é enfadonho, cheira a sepulcro, traz certa contração cadavérica”. Nesse mesmo grupo, o último capítulo é o "13” (LXXXIII), no qual se fica sabendo que Lobo Neves recusara a presidência de província com base em várias coincidências em torno do algarismo, e na décima quarta semana, o "13" final é invertido em "31" inicial (capítulo CX), dia da nova nomeação de Lobo Neves, que dispõe especularmente a ordem dos algarismos, a decisão do marido de Vírgília, a organização dos capítulos em seus grupos correspondentes, evidenciando quão "profundas que são as molas da narrativa”, nas palavras de Brás Cubas autor.

Voltando aos capítulos de corte, a aventura, o mistério e os efeitos decorrentes do modo de leitura ligado ao romance-folhetim são, ainda uma vez, desconstruídos: "O primeiro beijo" (capítulo XIV, último do grupo de capítulos de 1o de abril de 1880) destrói mais uma vez a expectativa de romance, posto que o herói de folhetim esvaziado é hesitante e desaparece na carreira seguidamente ao beijo rápido e quase roubado à Marcela; "O embrulho misterioso" (capítulo LII, último do grupo de 1 o de julho de 1880) tem pouco mistério e o pouco que tem é resolvido no próprio capítulo; por fim, uma carta "A um crítico" (capítulo CXXXVIII, último do grupo de 1o de novembro de 1880) prepara a recepção especializada do livro, desautorizando o leitor-crítico (Guimarães, 2004, p.175-93).

Nesse contexto, chama especial atenção o primeiro grupo de capítulos das Memórias, publicados na Revista Brasileira em 15 de março de 1880, nove partes que vão de "O óbito do autor" a "Transição”. Paralelamente ao "discurso do método" (Zilberman, 2012, p.80-5), interessam o uso retórico dos capítulos e, outra vez, a configuração do corte no romance seriado.

Em relação ao primeiro assunto, o capítulo nove, quer na revista ou no livro, tem ainda novidades a revelar: 


\section{Capítulo IX - Transição}

E vejam agora com que destreza, com que arte, faço eu a maior transição deste livro. Vejam: o meu delírio começou em presença de Virgília, Virgília foi o meu grão pecado da juventude; não há juventude sem meninice; meninice supõe nascimento; e eis aqui como chegamos nós, sem esforço, ao dia 20 de outubro de 1805, em que nasci [...]. (Machado de Assis, 2008d, v.1, p.637)

Na Revista Brasileira, o capítulo "Transição", além da autorreferenciação e dos mecanismos poéticos do jornal que serão esmiuçados, mostra que a real transição do enredo foi diluída ao longo do primeiro, quinto e sextos capítulos do grupo, principalmente no sexto (capítulo VI - "Chimène, qui l'eut dit? Rodrigue, qui l'eut cru?"), tornando-se o "gancho" um processo reverso. Nesse conjunto inaugural de capítulos, o primeiro deles conta que uma senhora chorou muito por ocasião da morte do narrador-defunto e o leitor é incitado a aguardar uma explicação; no quinto, "aparece a orelha dessa senhora”, e se sabe que Brás Cubas e ela se haviam amado anos antes, informação que, assim deslocada, esmaece de antemão a função tradicional do capítulo de transição; no sexto capítulo, o defunto-autor rememora, sem contar os fatos, mas com lirismo rebatido por comentários cínicos, a emoção dos amores idos e da visita que lhe fizera a ex-amante e namorada Virgília, em seu leito de morte. Amores proibidos do passado revelados dentro do próprio grupo de capítulos, o nono deles, tal como aquele vigésimo-segundo, "Volta ao Rio", chama a atenção para o seu lugar de transição, para o procedimento em si, sem que o corte constitua efetivamente, como se disse, o gancho com a quinzena seguinte.

A seguir, com o romance já publicado em livro, o capítulo IX passa a funcionar como um daqueles momentos bastante digressivos, quase incompreensíveis, por meio dos quais o narrador-personagem expõe, na análise de Roberto Schwarz (1990), com prejuízo de sua própria imagem e de sua classe, certa superioridade em relação ao leitor. Dessa perspectiva, aliás, muitos dos capítulos citados ou analisados, na posição de corte ou início de grupo, funcionam da mesma maneira. 
Ainda no capítulo IX, ao transitar entre acontecimentos e épocas para compor a sua autobiografia, o narrador coloca seus leitores, à primeira vista, diante de um método dedutivo ou, ainda, diante de uma narrativa que imita rudimentarmente o padrão da memória, no qual uma lembrança leva à outra. No entanto, o texto está apoiado sobre uma estrutura retórica determinante, em que as associações "livres" seguem um esquema rígido de movimentação, por meio da anadiplose:

1. O meu delírio começou em presença de Virgília,

2. Virgília foi o meu grão pecado da juventude;

3. Não há juventude sem meninice;

4. Meninice supõe nascimento; e eis aqui como chegamos nós, sem esforço, ao dia 20 de outubro de 1805 , em que nasci.

O trecho joga com a naturalidade das relações temporais e da memória que são recriadas pela figura de estilo por meio da qual se retoma a última palavra de uma proposição na primeira da proposição seguinte, de modo que a repetição marca as ligações entre as ideias e promove o encadeamento delas, como se vê no esquema:

1. Delírio [...] Virgília

2. Virgília [...] juventude

3. juventude $[\ldots]$ meninice

4. meninice $[\ldots]$ nascimento

As ligações são feitas simplesmente pela estrutura pendular, a partir da qual o narrador, de certa forma, salta de seu delírio ao nascimento, no ir e vir que passa pelas palavras "Virgília", "juventude" e "meninice". É preciso ressaltar que não há "destreza" e "arte" na transição em si, a qual obedece a uma estrutura previamente montada. Na realidade, o narrador-memorialista conta a sua história, organizando os trechos dela a seu bel-prazer, atitude comum à estratégia do cronista nos jornais, já há muitos anos.

$\mathrm{Na}$ dinâmica da passagem entre assuntos, o capítulo IX retoma diretamente recursos da crônica machadiana e da escrita da crônica 
em geral. O efeito de coesão textual produzido no trecho citado do romance de 1880, como acontecera em um texto jornalístico de 1864, decorre de construção retórica, já que nada se liga naturalmente a nada. A seguir, o trecho da crônica de 20 de agosto de 1864 é exemplar de dezenas de outros semelhantes. Ele faz a transição entre dois assuntos, em meio à variedade dos comentários que pedia a semana encerrada, e o narrador se dirige ao seu leitor, dizendo:

Nada mais natural do que passar de uma casa de livros a uma casa de óculos. É com os óculos que muita gente lê os livros. Se se acrescentar que muita gente lê os livros sem óculos, mas que precisa deles para ver ao longe, e finalmente uma classe de homens que vê perfeitamente ao longe e ao perto, mas que julga de rigor forrar os olhos com vidros, como forra as mãos com luvas, ter-se-á definido a importância de uma casa de óculos e a razão por que ela pode entrar no folhetim. ${ }^{21}$

Entre os vários assuntos de 20 de junho de 1864, o narrador-cronista comenta a edição que a casa Garnier preparara para $O$ demônio familiar, de José de Alencar. Próximo tópico, a inauguração de uma casa de óculos, além da necessidade de atingir o pretendido efeito de naturalidade na transição, assunto e métodos operados pelo trecho citado. Nesse caso, utilizando-se de uma lógica falsa, o narrador argumenta por meio de um silogismo, embutindo em sua narrativa duas premissas e uma conclusão:

1. Muita gente lê os livros com os óculos;

2. Ao falar de livros, é natural falar-se de óculos e dos vários usos dos óculos;

Conclusão - D'onde se conclui que uma casa de óculos pode ser matéria da crônica e, nas entrelinhas, que o narrador arranjou bem a transição entre os assuntos.

21 Machado de Assis, “Ao Acaso”, Diário do Rio de Janeiro, Rio de Janeiro, 20 jun. 1864, rodapé, p.1. 
A relação de generalidade/particularização que deveria haver entre a primeira premissa desmembrada na segunda e na retomada lógica da conclusão é falsa. Ao montar o argumento, o narrador-cronista faz acréscimos que preenchem a forma lógica com matéria estranha a ela, trazendo para o texto jornalístico a incongruência paródica do modelo de raciocínio que expandiria no romance, como recurso para a crítica, o riso e o juízo móvel, entre outros. Os procedimentos literários da crônica foram intensificados na narrativa, na qual a morte de Brás Cubas também não se liga naturalmente ao seu nascimento por meio dos fatos particulares que ele elege para redesenhar essa história.

Em ambos os casos, o particular aparentado geral pelo uso da retórica está a serviço dos efeitos que o narrador pretende criar. Para além da estratégia narrativa, os dois narradores são provocativos e encetam uma atitude que sempre exigiu de seu leitor participação ativa na construção de significados. ${ }^{22}$ Outra relação evidente entre eles é que ambos precisam transitar entre assuntos, pois sua escrita montada a partir de fragmentos exige mecanismos para isso. Por um lado, na leitura dominical da crônica, as partes são apanhadas em um só comentário e as remissões vão, como se viu, além do universo de leitura do periódico em que a crônica é publicada. A seguir, os encaminhamentos habituais da memória dos leitores são remontados pelo romance, ${ }^{23}$ que traz para o registro do ficcional a prática da leitura hipertextual dos jornais, explicitando-a nas remissões, interrupções e saltos indicados. Por outro lado, no desenrolar do enredo, a impressão de que a memória vem por fragmentos é dada, em parte, pelas acelerações e refreamentos da narrativa da ação, que supera o romance-folhetim, mas não ingressa em algo mais doutrinário, quer científico quer filosófico, frustrando frívolos e graves.

22 Esse último assunto é discutido em profundidade por Hélio Guimarães (2004).

23 Juracy Assmann Saraiva (1993) estudou a representação dramática do narrador em alguns romances de Machado de Assis, considerando as Memórias Póstumas de Brás Cubas aquele que dá início ao processo. O narrador é analisado formalmente, em profundidade, relacionado aos outros elementos da composição, e o tema da memória é destacado pela estudiosa em seu trabalho pioneiro. 
Por fim, algo já evidente na crônica explode no romance: o narrador chama a atenção o tempo todo para si, expondo dúvidas, demasiadas certezas ou incitando seus leitores a ações, entre outros recursos. Essa autorreferenciação exagerada, que evidencia um dos elementos textuais de antemão, também é prática de leitura dos periódicos, à maneira do olhar que o leitor voltava sobre o texto das citações que se destacavam, já plasticamente. Estamos diante do realce e intensificação que a escrita para os jornais requer diante da "atenção flutuante" do leitor, contrapartida da "livre associação" proposta pelo autor (e pela nova mídia), em termos de leitura. ${ }^{24}$

Assim, em Memórias Póstumas de Brás Cubas, o que aparece como novidade literária e ajudou a fazer a história do romance é, em parte, transposição de uma manobra retórica da crônica jornalística e da própria Poética da escrita dos jornais. As partes graficamente separadas (na página do jornal, nas partes da crônica, no romance machadiano de capítulos curtos) guardam o traço indelével da disjunção em conjunto, grande arte de Brás Cubas como autor-defunto. No rejunte que une a fina cerâmica do texto em mosaico, uma argamassa que os narradores machadianos pigmentam por vezes com cores contrastantes, está parte da arte literária propiciada pela matriz jornalística. O vaivém constante entre parte e todo é a estratégia de ordenação da narrativa no romance inovador, na crônica e no próprio jornal. A literatura imita, assim, aquele "sistema complexo e um pouco disparate de ordenação do mundo" já mencionado na primeira parte deste livro, que nos fala da coisa em si, mas também de sua escrita (Thérenty, 2007, p.78).

Em um contexto amplo, aquele que deu forma "à tensão entre escrita e impressão" e que "melhor soube articular essa vinculação entre a produção literária local com a publicação em jornal”

24 O empréstimo dos conceitos psicanalíticos aqui é apenas com finalidade de construir uma imagem e não tem a intenção anacrônica de ler antecipações em Machado de Assis. No limite, pode-se pensar que a Psicanálise é um método de tratamento inserido na história de seu tempo, no qual novas práticas de escrita e leitura se tinham tornado possíveis, e que propunha significar e ressignificar a partir de fragmentos aparentemente desconexos. 
(Süssekind, 1993, p.188) criou parte da novidade literária de sua obra ficcional, tornando-se o escritor capital da Literatura Brasileira, a partir da imitação de um procedimento comum à prática de publicação do romance-folhetim no Brasil: a arbitrariedade do corte naqueles capítulos cuja alma estava também nos ganchos, exemplificada na primeira parte deste livro, que deixava o leitor brasileiro das narrativas nos jornais a ver ou a esperar navios.

Nesse caso, o efeito elástico produzido pelas peculiaridades da publicação do romance-folhetim no Brasil foi lido pela escrita literária de um escritor-jornalista para quem a arte constituiu-se íntima e fortemente como forma de consideração de seu suporte, como possibilidade de escrita da novidade, que se materializa como incorporação formal paródica das práticas de publicação e leitura literária nos periódicos. Nos exemplos em questão, a novidade formal circulou, ainda, desde a adaptação da publicação do romance-folhetim francês pelos jornais até a revista, que supunha outro tipo de publicação seriada da narrativa longa.

No século XIX, a pena machadiana inventava sua escrita dentro do universo textual em mosaico no qual se movia habilmente, a partir das inúmeras colunas/textos com as quais colaborou para os jornais e revistas à sua época. Voltando, mais uma vez, ao leitor da imprensa e de Machado de Assis nesses periódicos, quem sabe se os "maus hábitos" produzidos pela desfiguração de características tão importantes quanto o gancho no romance-folhetim não tenham representado, para a Literatura Brasileira, uma vantagem? Se o leitor não clamava tão fortemente por ser "agradado", a forma da ficção em fatias que ocupava o rodapé dos jornais ou as páginas das revistas pode ter ganhado contornos imensamente mais largos que os dos romances-folhetins europeus, o que explicaria, em parte, como os nossos escritores puderam publicar uma Literatura tão experimental nos periódicos, notadamente no caso de Machado de Assis. 